\title{
An analysis of personnel dose reports in medical radiation occupational workers from an oncology center
}

\author{
S. Sathiyan ${ }^{1}$, M. Ravikumar ${ }^{1}$, R. Ravichandran ${ }^{2 *}$
}

${ }^{1}$ Department of Radiation Physics, KMIO, Bangalore, India

${ }^{2}$ National Oncology Center, Royal Hospital, Muscat, Oman

\begin{abstract}
\section{Short report}

\section{*Corresponding author:}

Dr. Ramamoorthy Ravichandran,

Fax: +96824627004

ravichandranrama@rediffmail.com

Accepted: Nov. 2015

Int. J. Radiat. Res., April 2016;

DOI: 10.18869 /acadpub.ijrr.14.2.143

Background: To evaluate the risk involved, there is need to know the quantum of personnel exposures in whole service. Dose reports from an Oncology Centre over 7 block periods, 5 years each from 1979 till 2013 are analyzed. Materials and Methods: Personnel monitoring (PM) reports till 1990 s with film badges and later thermoluminescent ( $T L$ ) badges ( $\mathrm{CaSO}_{4}$. Dy) were evaluated. 35 years total service was taken to represent total professional service of staff superannuating at age 60 years. Results: Mean personnel equivalent dose for 5 year block period is $3.30 \pm 0.43 \mathrm{mSv}(\mathrm{n}=7$ blocks). Maximum dose in any block period was 30-60 mSv. Equivalent doses $22 \%$ were zero, $64.3 \%$ within $5 \mathrm{mSv}$. $2.1 \%$ were above $30 \mathrm{mSv}$ in 5 year periods. Doses were decreasing order $11.8 \mathrm{mSv}$ (radiopharmaceutical preparation), $4.3 \mathrm{mSv}$ (nuclear medicine), $4.1 \mathrm{mSv}$ (medical physics), $2.2 \mathrm{mSv}$ (brachytherapy); $1.2 \mathrm{mSv}$ (radiodiagnosis), $1.1 \mathrm{mSv}$ (external beam radiotherapy) and $0.73 \mathrm{mSv}$ (radiation sterilization plant). Conclusion: The whole body personnel dose in are much lower than recommended annual dose equivalent limits of $100 \mathrm{mSv} / 5$ years. The magnitude of recorded doses to staff show that the risk is negligible and the principle of ALARA is being practiced in the work areas.
\end{abstract}

E-mail:

Revised: Oct. 2015 14(2): $143-148$ Keywords: Occupational exposures, Radiation Risk, Personnel monitoring,
TLD Badges.

\section{INTRODUCTION}

Low magnitude external exposures are encountered by personnel during routine work in handling radiation sources during their service. In radiation protection, the established model for determining carcinogenic effects at low doses is based on the "linear no threshold model" (LNT), has major implication of no threshold for stochastic effects regardless of how low they are $(1,2)$, the hypothesis continues that the cancer incidence increases proportionally with radiation dose.

The Biologic Effects of Ionizing Radiation (BEIR VII) report (3) defines low doses as those in the range of near zero up to about $100 \mathrm{mSv}$
(0.1Sv) of low LET radiation. BEIR VII does not support the hypothesis that at low doses of radiation there are beneficial effects. Some risk potential for carcinogenesis must be accepted at any level of protection. Therefore, current belief is that exposure to ionizing radiation, no matter how small, carries a risk of detriment with the risk being proportional to the dose accumulated. Therefore, the concept of 'As low as reasonably achievable (ALARA) is practiced (1).

There is a controversy raised that LNT hypothesis for cancer risk appears scientifically unfounded and invalid in favour of a threshold or hormesis (4). Also it was postulated that by exposing cells to a low dose of ionizing radiation would make them less susceptible to a later high 
dose exposure. Even a beneficial effect of low dose of ionizing radiation, termed hormesis, believes that metabolic detoxification and cell repair benefits arise from doses in the range of 1-50 mSv. Increasing evidence in the literature over the past 25 years indicates that adaptive protection responses occur in mammalian cells in-vivo and in-vitro after single as well as protracted exposures to $\mathrm{X}$ - or gamma radiation at low doses.

In these circumstances, there is need for assessing dose levels in a medical institution to know the quantum of personal exposures and also justify present work practices and safety of work environment. Radiation dose records of radiation workers throw light on the degree of compliance of legal regulations (dose limits), and the effectiveness of 'as low as reasonably achievable' (ALARA) principles. The present work attempts to analyze the personnel monitoring dose records of staff from a major oncology centre, over a period of 35 years, which might represent life time personnel exposure of staff members.

\section{MATERIALS AND METHODS}

Kidwai Memorial Institute of Oncology is a regional cancer center at Bangalore involved in cancer treatment services since 1973. The increased application of radiation sources have started in 1980, with increase in teletherapy machines, a regional center for radiopharmaceuticals supplying readily injectable technetium-99m radiopharmaceuticals. All the radiation workers are monitored using personnel monitoring (PM) services as per statutory conditions. Table 1 shows the list of occupational workers working in different departments. The representative patient loads in different treatment modalities are indicated in table 2. Film badges in metal cassettes supplied by Bhabha Atomic Research Center (BARC) up to $1990 \mathrm{~s}$ and thermo luminescent (TL) badges (CaSo4.Dy) till 2005 were used for personnel monitoring. Subsequently the issue of TLD badges and dose evaluation is carried out by M/s Avanttec India, Chennai. Dose records are maintained by regulatory authority in Mumbai.

Personnel dose records obtained by the institute for block periods 1994-1998, 1999-2003, 2004-2008, and 2009-2013 were analyzed to estimate the mean radiation doses per staff member. From cumulative values at the end of 1998 block, subtracting the five year contribution of doses, the history of starting cumulative dose value for period ending 1993 are obtained. As new staff came in the year

Table 1. Number of radiation workers monitored an their duties.

\begin{tabular}{|c|c|c|c|c|c|c|c|c|}
\hline \multirow[b]{2}{*}{$\begin{array}{l}\text { Block } \\
\text { Periods }\end{array}$} & \multirow[b]{2}{*}{$\begin{array}{l}\text { Total Number } \\
\text { Monitored }\end{array}$} & \multicolumn{7}{|c|}{ Number of radiation workers and departments } \\
\hline & & $\begin{array}{l}\text { Radio- } \\
\text { Diagnosis }\end{array}$ & $\begin{array}{c}\text { Radia } \\
\text { Oncol } \\
\text { Ext.RT }\end{array}$ & $\begin{array}{l}\text { ion } \\
\text { ogy } \\
\text { BT } \\
\end{array}$ & $\begin{array}{l}\text { Radiation } \\
\text { Physics }\end{array}$ & $\begin{array}{l}\text { Nuclear } \\
\text { Medicine }\end{array}$ & $\begin{array}{l}\text { Radio- } \\
\text { Pharmacy } \\
\text { (RCR) }\end{array}$ & $\begin{array}{c}\text { Radiation } \\
\text { Sterilization } \\
\text { Plant }\end{array}$ \\
\hline Till 1993 & 152 & 12 & 65 & 22 & 13 & 19 & 10 & 11 \\
\hline 1994-1998 & 152 & 12 & 65 & 22 & 13 & 19 & 10 & 11 \\
\hline 1999-2003 & 183 & 11 & 46 & 53 & 15 & 35 & 10 & 11 \\
\hline 2003-2008 & 163 & 18 & 57 & 34 & 21 & 22 & 4 & 7 \\
\hline $2009-2013$ & 154 & 11 & 40 & 46 & 15 & 26 & 7 & 9 \\
\hline
\end{tabular}

Table 2. Patients' data showing work load on nature of occupational work.

\begin{tabular}{|c|c|c|c|c|c|c|c|c|c|c|}
\hline \multirow[t]{2}{*}{ Year } & \multicolumn{4}{|c|}{$\begin{array}{l}\text { No. of patients/year relating to amount of } \\
\text { radiation work }\end{array}$} & \multirow{2}{*}{\multicolumn{2}{|c|}{$\begin{array}{c}\text { Manual BT } \\
\text { Activity } \\
\text { Handled/yr GBq } \\
\text { Ci }\end{array}$}} & \multicolumn{4}{|c|}{$\begin{array}{c}\text { Nuclear Medicine } \\
\text { Activity /year Tc99m/ I-131 }\end{array}$} \\
\hline & Ext.RT & Man.BT & RAL BT & I-131 Ther & & & GBq & $\mathrm{Ci}$ & GBq & $\mathrm{Ci}$ \\
\hline 1991 & 3519 & 221 & 411 & 85 & 2044 & 55.3 & 1332 & 36 & 471.8 & 12.8 \\
\hline 1999 & 2815 & 395 & 46 & 101 & 3036 & 82.1 &, & $" \prime$ & 560.6 & 15.2 \\
\hline 2001 & 3537 & 305 & 32 & 159 & 2240 & 60.5 & ", & $"$ & 882.5 & 23.9 \\
\hline 2004 & 3863 & 460 & 49 & 118 & 6297 & 170.2 & $\prime \prime$ & , & 654.9 & 17.7 \\
\hline
\end{tabular}


1980, the cumulative dose of personnel at 1993 taken as a representative value for 3 block periods (1979-1983, 1984-1988, 1989-1993) together.

The total period is about 35 years of occupation ( 7 block periods of 5 years). 5 years averaging of total number of personnel was carried out. Study is undertaken taking that the mean exposure per year will represent the genuine radiation risk to medical radiation workers due to their occupational work. For brachytherapy, and nuclear medicine, to represent the radiation exposure, the amount of activities of Casium-137 and Iodine-131 were taken on representative years (refer table 2) to calculate approximate radiation dose based on of $1 \mathrm{~m}$ exposure rates, and the total number of patients involved.

\section{RESULTS}

Table 1 shows that more radiation workers are in radiation therapy (external beam, brachytherapy) and nuclear medicine services. Table 3 shows the cumulated exposures of staff for various block periods. First row represents three block periods of 15 years. The last column of this table shows the mean doses received the staff in various block periods. Mean equivalent dose received per staff for 5 year block period is $3.30 \pm 0.43 \mathrm{mSv}$ (mean of 7 block periods, 35 years). Based on this average value, it implies that the mean total dose in 35 years will be 23.1 $\mathrm{mSv}$, assuming a total radiation work is 35 years in this institute. In table 4 the number of persons receiving various dose values are classified and shown. It could be observed that on an average $22 \%$ of the personnel receive zero doses; about $86 \%(64 \%+22 \%)$ of the staff receive doses not exceeding $5 \mathrm{mSv}$ for 5 year block periods ( $<35 \mathrm{mSv}$ in 7 block periods, @ 1 $\mathrm{mSV} /$ year) ; and $92 \%$ of the staff receive only doses $<10 \mathrm{mSv}$ ( 7 block periods).

From table 4 , the total radiation dose (Committed dose equivalent) in 35 years amounts to 18.572 man Sv from equation 1 for all staff cumulating for entire service.

Total Man Sv $=804$ (Total staff) $\times\left(\mathbf{3 . 3 0} \times \mathbf{1 0}^{-3}\right.$

Sv $/ \mathbf{5 y e a r}$ period $) \times \mathbf{3 5}$ years $=\mathbf{1 8 . 5 7 2}----(1)$

As many staff have to retire after $30-35$ years of service, a few enter and leave service, this might represent the total manSv of the institute during entire service. In tables 5 and 6 , the breakup of cumulated dose for different departments are shown. The trend of quantum

Table 3. Cumulated Doses for total occupational workers.

\begin{tabular}{|c|c|c|c|c|c|}
\hline Block & Total & \multicolumn{4}{|c|}{ Cumulated doses during block (mSv) } \\
\cline { 3 - 6 } Periods & Number & Minimum & Maximum & Mean (SD) & mSv/5yrs Blk \\
\hline 1980-1994 (3Blks) & 152 & $0(n=41)$ & 147.9 & $11.47(22.8)$ & 3.82 \\
$1994-1998$ & 152 & $0(n=27)$ & 40.3 & $3.24(4.9)$ & 3.24 \\
$1999-2003$ & 183 & $0(n=33)$ & 39.2 & $3.21(6.2)$ & 3.21 \\
$2004-2008$ & 163 & $0(n=26)$ & 31.4 & $2.67(4.7)$ & 2.67 \\
$2009-2013$ & 154 & $0(n=47)$ & 60.4 & $3.58(8.0)$ & 3.58 \\
Total & 804 & & & & Mean 7 Blks \\
& & & & & \\
\hline
\end{tabular}

Table 4. Cumulated doses in block periods and number of persons.

\begin{tabular}{|c|c|c|c|c|c|c|c|c|}
\hline Block & Total & \multicolumn{7}{|c|}{ No. of personnel and Range of Doses Received (mSv) } \\
\cline { 3 - 9 } Periods & Number & $\mathbf{0}$ & $\mathbf{0 - 5}$ & $\mathbf{5 - 1 0}$ & $\mathbf{1 0 - 2 0}$ & $\mathbf{2 0 - 3 0}$ & $\mathbf{3 0 - 4 0}$ & $\mathbf{7 4 0}$ \\
\hline $1979-199$ (3Blks) & 152 & $41(27 \%)$ & $70(46.0 \%)$ & $15(9.9 \%)$ & $8(5.3 \%)$ & $6(3.9 \%)$ & $4(2.6 \%)$ & $8(5.2 \%)$ \\
$1994-1998$ & 152 & $27(17.8 \%)$ & $107(70.4 \%)$ & $12(7.9 \%)$ & $4(2.6 \%)$ & $1(0.7 \%)$ & --- & $1(0.7 \%)$ \\
$1999-2003$ & 183 & $33(18.0 \%)$ & $132(72.1 \%)$ & $9(4.9 \%)$ & $3(1.6 \%)$ & $4(2.2 \%)$ & $2(1.1 \%)$ & --- \\
$2004-2008$ & 163 & $26(16.0 \%)$ & $122(74.8 \%)$ & $7(4.3 \%)$ & $6(3.7 \%)$ & $1(0.01 \%)$ & $1(0.01 \%)$ & --- \\
$2009-2013$ & 154 & $51(33.1 \%)$ & $86(55.8 \%)$ & $8(5.2 \%)$ & $2(1.3 \%)$ & $6(3.9 \%)$ & --- & $1(0.7 \%)$ \\
& 804 & $178(22 \%)$ & $517(64.3 \%)$ & $51(6.34 \%)$ & $23(2.9 \%)$ & $18(2.24 \%)$ & $7(0.9 \%)$ & $10(1.2 \%)$ \\
\hline
\end{tabular}


of mean exposures (for 5 year periods) are in the decreasing order, highest in radiopharmaceutical preparation work $11.8 \mathrm{mSv}$, nuclear medicine $4.3 \mathrm{mSv}$, medical physics 4.1 $\mathrm{mSv}$; brachytherapy $2.2 \mathrm{mSv}$; radiodiagnosis 1.2 $\mathrm{mSv}$; external beam radiotherapy $1.1 \mathrm{mSv}$ and radiation sterilization plant $0.73 \mathrm{mSv}$. Radiation sterilization plant staff received least amount of personnel exposures as the concrete bunker is built with excess shielding.

\section{DISCUSSION}

This study has brought out the scenario in a major oncology center. From tables 5 and 6 it could be inferred that there was maximum dose of 133.5 and $147.9 \mathrm{mSv}$ for radiation worker in medical physics and radiopharmaceutical preparations appear to higher (refer first row), values for 3 block periods together, with a mean value of about 9-10 mSv per year. This does not exceed a value neither $50 \mathrm{mSv}$ per calendar year (permissible value before 1990) nor $100 \mathrm{mSv}$ per 5 year blocks (permissible value as per present guidelines).

A study on occupational workers in nuclear plant (5) with a long follow-up period (average 26.1 years) showed that cumulated doses $0-20$ $\mathrm{mSv}, 20-100 \mathrm{mSv}$ and $>100 \mathrm{mSv}$ were received by $87.3 \%, 10.8 \%$ and $1.9 \%$ workers respectively. This therefore showed only $2 \%$ of the monitored workers received cumulative external-radiation doses in excess of $100 \mathrm{mSv}$, and three-quarters of the workers had recorded doses below 10 $\mathrm{mSv}$. From our data over a period of 7 block periods, the global mean exposure for 5 year periods is $3.30 \mathrm{mSv}$ ( $330 \mathrm{mRem}$ ) which is almost equivalent to one year exposure to natural radiations. From table 4 it could be observed that $85 \%$ of the staff received total of $10 \mathrm{mSv}$ during the 7 block periods of 35 years, which almost similar to the findings of $75 \%$ of staff receiving less than $10 \mathrm{mSv}$ from a nuclear plant illustrated earlier (5).

In the present data, the external beam RT staff showed a mean of $<1.5 \mathrm{mSv}$ per block period, compared to brachytherapy staff showing mean of about $3.0 \mathrm{mSv}$, but this is much lower than the permissible dose of $100 \mathrm{mSv}$ in one block period of 5 years. Bulk of the patient treatments of external beam radiotherapy in this institute are only by telecobalt machines. During 1985 to 1995 more patients in brachy therapy received treatment with Selectron MDR (M/s Nucletron, Netherlands) and parallely manual brachytherapy with Cs 137 (Amersham International, UK) sources were carried out.

From table 2 if we take the total number of patients by brachytherapy is 305 , and about 20 $\mu \mathrm{Sv}$ per patient (total exposure $60 \mathrm{mSv} / \mathrm{yr}$ ), averaged in 53 staff will indicate an exposure of $1 \mathrm{mSv} / \mathrm{yr} / \mathrm{staff}$. This works out to be about $5.0 \mathrm{mSv} / 5$ year block period. Taking 159 patients in I-131 therapy, $5 \mu \mathrm{Sv}$ per patient (total exposure $8 \mathrm{mSv} / \mathrm{yr}$ ); about 1000 patients in imaging with an exposure of $2 \mu \mathrm{Sv}$ per patient (total $20 \mathrm{mSv} /$ year); distributed among 35 staff indicates a mean exposure of (28 $\mathrm{mSv} / 35 \mathrm{staff})$ $0.8 \mathrm{mSv} /$ year. This amounts to $4 \mathrm{mSv} / 5$ year block period. The above calculations are just to represent a kinetic model for hazard evaluation purposes only, the true personnel dose history of course should be based on monitored dose values by physical TL detectors. Radiation sterilization plant personnel received exposures during 5 year periods about $1.0 \mathrm{mSv}$ which is apparent because of the premises planned for industrial type of design, and almost similar to the external beam radiotherapy exposures.

Among A-bomb survivors, uncertainty remains whether whole-body doses of less than $200 \mathrm{mSv}$ have increased the risk of cancer. Extrapolation from data on survivors exposed to more than $200 \mathrm{mSv}$, using a linear no-threshold model to predict effects at lower doses, yields an estimate of the relative risk of cancer (excluding leukemias) ${ }^{(6-8)}$ equal to $0.41 \%$ for each $10 \mathrm{mSv}$ increment. The risk estimation in the present perspective as for the LNT model, the validity of assumption of linearity of dose response at low doses is recognized to remain in doubt (9). In this review it was clarified that ICRP's recommendations (1) are aimed at prospectively for planning and optimization of occupational and public exposures and retrospectively for demonstrating compliance with dose limits for regulatory purposes in radiological protection; 
not for the estimation of risk. Another report (10) highlighted that a study from interventional cardiologists (11) working in cath lab matched with unexposed controls without radiation exposures have shown adaptive response to radiation. Two important experimental studies on the effect of low doses (12) has brought out that radiation is necessary for proper cell functions. Therefore it is becoming clear that up to $100 \mathrm{mSv}$ (10 cGy) cumulated doses have a much lower risk.

The present analysis of personnel exposure data has brought out an important point that in a major hospital environment, due to occupational radiation work, a mean cumulated dose of about 3-4 mSv only is received per 5 year block periods on an average. This works out to be about $20-30 \mathrm{mSv}$ only in the entire service of 35 years. The data also revealed that $80 \%$ of the total staff have received $<5 \mathrm{mSv} / 5$ year block period is an encouraging information to overcome the myth that radiation work carries more risk. As hospitals engage in life saving procedures, this present report could prevent the fear to take up radiation related medical occupational work.

\section{ACKNOWLEDGEMENTS}

Authors thank Director, Kidwai Memorial Institute of Oncology, Bangalore for the kind permission for analyzing the personnel monitoring records of institute staff.

Table 5. Personnel doses (mSv) in different departments on various block periods (from beam generating radiation sources).

\begin{tabular}{|c|c|c|c|c|c|}
\hline Block Period & $\begin{array}{l}\text { Radio Diagnosis } \\
\text { Min Max Mean }\end{array}$ & $\begin{array}{l}\text { Radiotherapy } \\
\text { (Beam Therapy) } \\
\text { Min Max Mean }\end{array}$ & $\begin{array}{l}\text { Radiotherapy } \\
\text { (Brachy Therapy) } \\
\text { Min Max Mean }\end{array}$ & $\begin{array}{l}\text { Medical Physics } \\
\text { (RT, BT, NM) } \\
\text { Min Max Mean }\end{array}$ & $\begin{array}{l}\text { Radiation } \\
\text { Sterilization Plant } \\
\text { Min Max Mean }\end{array}$ \\
\hline $\begin{array}{l}\text { 1979-93 } \\
\text { (3 Blocks) }\end{array}$ & $\begin{array}{lrr}0 & 4.5 & 1.47 \\
n=12 & \text { (SD } 1.4)\end{array}$ & $\begin{array}{lrc}0 & 54.0 & 3.46 \\
n=65 & (S D ~ 8.5)\end{array}$ & $\begin{array}{lrr}0 & 41.5 & 3.86 \\
n=22 & \text { (SD } 8.8)\end{array}$ & $\begin{array}{lll}0 & 133.5 & 19.3 \\
n=13 & (S D & 35.3)\end{array}$ & $\begin{array}{lrc}0 & 2.5 & 1.56 \\
& \end{array}$ \\
\hline 1994-1998 & $\begin{array}{lrr}0 & 4.5 & 1.45 \\
n=12 & (S D ~ 1.4)\end{array}$ & $\begin{array}{lrr}0 & 12.5 & 1.65 \\
n=65 & (S D 2.3)\end{array}$ & $\begin{array}{lcc}0 & 17.3 & 2.56 \\
n=22 & (S D ~ 3.8)\end{array}$ & $\begin{array}{lrr}0 & 6.6 & 3.19 \\
n=13 & (S D 2.4)\end{array}$ & $\begin{array}{lr}0 & 3.5 \\
n=11 & (S D ~ 0.9)\end{array}$ \\
\hline 1999-2003 & $\begin{array}{lrr}0 & 9.1 & 1.49 \\
n=11 & (S D ~ 2.6)\end{array}$ & $\begin{array}{lrr}0 & 5.0 & 1.37 \\
n=46 & (S D ~ 1.4)\end{array}$ & $\begin{array}{lrr}0 & 39.0 & 2.97 \\
n=53 & (S D 7.8)\end{array}$ & $\begin{array}{lr}0 & 29.0 \quad 4.63 \\
n=15 \quad(S D ~ 8.0)\end{array}$ & $\begin{array}{lc}0 & 2.0 \\
n=11 & \text { (SD 0.7) }\end{array}$ \\
\hline $2004-2008$ & 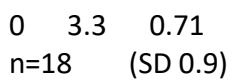 & $\begin{array}{lrr}0 & 6.1 & 1.00 \\
n=57 & \text { (SD 1.2) }\end{array}$ & $\begin{array}{lrr}0 & 31.4 & 4.51 \\
n=34 & (S D 7.2)\end{array}$ & $\begin{array}{lrr}0 & 4.4 & 1.31 \\
n=21 & (S D ~ 1.4)\end{array}$ & $\begin{array}{lrc}0 & 0.9 & 0.61 \\
n=7 & (S D ~ 0.3)\end{array}$ \\
\hline 2009-2013 & $\begin{array}{lrr}0 & 20.8 & 3.14 \\
n=11 & (S D ~ 6.3)\end{array}$ & $\begin{array}{lr}0 & 1.0 \quad 0.21 \\
n=40 & (S D ~ 0.3)\end{array}$ & $\begin{array}{lr}0 & 6.6 \\
n=12 & \text { (SD 1.7) }\end{array}$ & $\begin{array}{lrr}0 & 1.9 & 0.22 \\
n=12 & (S D & 0.5)\end{array}$ & $\begin{array}{lrr}0 & 5.4 & 0.86 \\
n=12 & (S D ~ 1.7)\end{array}$ \\
\hline
\end{tabular}

Table 6. Personnel doses (mSv) in on various block periods ( work with unsealed radiation sources).

\begin{tabular}{|c|c|c|c|c|c|c|}
\hline \multirow[t]{2}{*}{ Block Period } & \multicolumn{3}{|c|}{ Nuclear Medicine } & \multicolumn{3}{|c|}{ Radiopharmacy } \\
\hline & Min & Max & Mean & Min & Max & Mean \\
\hline 1980-94(3 Blocks) & $\begin{array}{c}0 \\
n=19\end{array}$ & $\begin{array}{l}64.4 \\
\text { (SD }\end{array}$ & $\begin{array}{l}16.2 \\
19.7)\end{array}$ & $\begin{array}{r}1.35 \\
\mathrm{n}=10\end{array}$ & 147.9 & $\begin{array}{c}38.8 \\
D 45.0)\end{array}$ \\
\hline 1994-1998 & $\begin{array}{l}0 \\
n=19\end{array}$ & 5.5 & $\begin{array}{c}2.7 \\
D 1.9)\end{array}$ & $\begin{array}{l}0 \\
n=10\end{array}$ & 40.3 & $\begin{array}{l}12.0 \\
12.7)\end{array}$ \\
\hline 1999-2003 & $\begin{array}{l}0 \\
n=35\end{array}$ & ${ }^{8.6}$ & $\begin{array}{c}1.7 \\
D 2.2)\end{array}$ & $\begin{array}{l}0 \\
n=19\end{array}$ & 25.5 & $\begin{array}{r}9.6 \\
\text { D } 9.7)\end{array}$ \\
\hline 2004-2008 & $\begin{array}{l}0 \\
n=22\end{array}$ & ${ }^{17.7}$ & $\begin{array}{c}3.4 \\
D 4.6)\end{array}$ & $\begin{array}{l}0 \\
n=4\end{array}$ & 17.4 & $\begin{array}{r}9.9 \\
D \quad 8.2)\end{array}$ \\
\hline $2009-2013$ & $\begin{array}{l}0 \\
n=26\end{array}$ & $\begin{array}{r}29.9 \\
\text { (S }\end{array}$ & $\begin{array}{r}6.2 \\
8.8) \\
\end{array}$ & $\begin{array}{l}0 \\
n=19\end{array}$ & 60.4 & $\begin{array}{r}12.1 \\
22.8)\end{array}$ \\
\hline
\end{tabular}




\section{Sathiyan et al. / An analysis of personnel dose from an oncology center}

\section{Conflict of interest: Declared none.}

\section{REFERENCES}

1. ICRP-60, International Commission on Radiological Protection. (1990) Recommendation of the International Commission on Radiological Protection. Annals of the ICRP, (1991), 21, Publication 60. Oxford: Pergamon Press.

2. United Nations Scientific Committee on the Effects of Atomic Radiation: Sources and effects of Ionizing Radiation (2006) UNSCEAR. Report to the General Assembly, with Scientific Annexes, United Nations, New York, 2008.

3. Biologic Effects of Ionizing Radiation (BEIR) VII: (2002) Health Risks from Exposure to Low Levels of Ionizing Radiation. National Academies Press, 500 Fifth Street, NW, Washington DC, 2001,.

4. Feinendegen LE (2005) Evidence for beneficial low level radiation effects and radiation hormesis. The British Journal of Radiology, 78: 3-7.

5. Ritz B, Morgenstern H, Froines J, Young BB (1999) Effects of exposure to external ionizing radiation on cancer mortality in nuclear workers monitored for radiation at Rocketdyne/ Atomics International. Amer J Ind Med, 35: 21-31.
6. Pierce DA and Preston DL (2000) Radiation-related cancer risks at low doses among atomic bomb survivors. Radiat Res, 154: 178-86.

7. Preston D, Ron E, Tokuokas, Funamutos, Nishi N, Soda M, Maduchi K (2007) Solid cancer incidence in atom bomb survivors 1958-1998. Radiat Res, 168: 1-64.

8. Pierce DA, Shimizu Y, Preston DL, Vaeth M, Mabuchi K (1996) Studies of the mortality of atomic bomb survivors. Report 12, Part I. Cancer: 1950-1990. Radiat Res, 146: 1-27.

9. Pradhan AS, Kim JL, Lee JI (2012) On the use of "effective dose" (E) in medical exposures. J Med Phys, 37: 63-65.

10. Ravichandran R (2013) Low magnitude occupational radiation exposures-are they safe or unsafe? Proceedings of XI Radiation Physics \& Protection Conference, 25-28 November 2012, Nasr City - Cairo, Egypt pages $233-238$.

11. Russo GL and Picano E (2012) The effects of radiation exposure on interventional cardiologists. Euro Heart J, 33: 423-424.

12. Smith GB, Battle G, Yair G, Navarrette, Guilmettee A, Raymond RA (2011) Exploring biological effects of low level radiation from the other side of background. Health Phys, 100: 263-265. 